Journal of Engineering and Applied Sciences 14 (19): 7036-7039, 2019

ISSN: 1816-949X

(C) Medwell Journals, 2019

\title{
A Study on Share Price Behaviour Around BuyBack and Dividend Announcements in India
}

\author{
${ }^{1}$ M.A. Deepashree and ${ }^{2}$ N. Suresh \\ ${ }^{1}$ Ramaiah University of Applied Sciences, 560054 Bangalore, India \\ ${ }^{2}$ Faculty of Management and Commerce, Ramaiah University of Applied Sciences, \\ 560054 Bangalore, India, nsuresh.ms.mc@msruas.ac.in
}

\begin{abstract}
Over the past few years in India, many companies have announced significant number of stock repurchases and dividends. Share repurchase have become an important area in financial research considering its strong implication for corporate policy. Buybacks were introduced in the year 1998, in India and it has received attention of all major companies. This study analyses: signaling effect of a share buyback and dividend announcements, the market reaction and share price behaviour around stock buybacks and dividend announcement, impact of buyback and dividend announcements on share price. The analysis uses 17 firms which have announced buybacks and dividends during the period 2015-2017. This study examines the signaling effect of share price by finding the abnormal return of the share price using 11 days $(-5,0,+5)$ event period. To find out whether buyback and dividend announcements has an impact on share prices "Autoregressive Conditional Heteroskedasticity" (ARCH) Model is used. Result shows that there is positive signaling of share prices around buyback and dividend announcements. Stock buyback announcement recorded high Cumulative Abnormal Returns (CAR). It implies that the market reacts more favorably to repurchases compared to dividend announcements.
\end{abstract}

Key words: Repurchase, abnormal returns, cumulative returns, dividends, buyback, ARCH

\section{INTRODUCTION}

Share repurchase (or stock buyback) is the re-acquisition by a company of its own stock. It represents a more flexible way of returning money to shareholders. The company either retires the repurchased shares or keeps them as treasury stock, available for re-issuance. Open market share repurchase and dividend initiation announcement are related with positive abnormal stock return. For the both payout methods the market reaction is of same magnitude. One of the alternatives for dividends is share repurchases. If a company repurchases its own shares, the number of shares held by the public will be reduced. Open market share repurchase is the most common share repurchase held in almost all the countries. A company will announce that it is going to repurchase its own shares in the open market from time to time as market conditions reveals that when and how much to repurchase. Open market share repurchases take months or even years. In USA, companies are allowed to do treasury operations in their stock whereas Indian companies have to necessarily cancel their shares pursuant to their buyback program (Tirumalvalavan and Sunitha, 2006).
The study uses open market share repurchase program for the analysis and it investigates the reaction of market to buyback and dividend announcements and option between two payout methods. The analysis uses data from SEBI website and NSE India in the period from 2015-2017.

Literature review: Evgeniou et al. (2018) studies a U-shaped relation between long-run excess returns after buyback authorization announcements and firm centrality in the input-output trade flow network. This study contributes to the literature on managerial market timing ability in the context of share repurchases. It also relates to the literature of investor's delayed and biased reactions to information. Andres et al. (2018) analyze the decision to announce an open market share repurchases and the share price reaction to the announcement, uses a conditional estimation approach which takes into account that the repurchase decision is made rationally. By using a conditional estimation approach in the context of repurchase announcements leads not only to more efficient estimates but also, at least to a certain extent, to the identication of different value drivers. Andriosopoulos and Lasfer (2015) analyzes a uniquely

Corresponding Author: N. Suresh, Faculty of Management and Commerce, Ramaiah University of Applied Sciences, 560054 Bangalore, India, nsuresh.ms.mc@msruas.ac.in 
constructed data set of open market share repurchases across a sample of European firms, focuses on the market valuation of share repurchases. There is a significant drop in excess returns following the change in legislation in the UK that allowed companies to treat their repurchased shares as treasury stocks. Chemmanur et al. (2010) studies firms rationale for undertaking ASR (Accelerated Share Repurchase) rather than the traditional Open Market Repurchase (OMR) programs, using a hand-collected sample of ASR announcements. Firms undertaking ASR programs are significantly larger than those undertaking OMR programs and that ASR programs have a larger median dollar amount of deal values than OMR programs.

\section{MATERIALS AND METHODS}

To analyze the signaling effect of buyback and dividend announcements on the share price of the announced companies an event window of 11 days consisting of the date of announcement, 5 days pre and 5 days post-announcement date has been selected. This would help us analyze the impact of the decision by announced companies on the share prices during the study period. We have also used a short event window consisting of $3,5,7$ days $(-1,0,+1)(-2,0,+2)(-3,0,+3)$, i.e., 1-3 days before and after announcement date for finding out the window which has highest mean.

The first step in the analysis of examining the signaling effect of a share buyback and dividend announcements requires computing the market adjusted Cumulative Abnormal Returns (CAR) for the sample of 17 firms over a 5 days trading period starting on the announcement date. By examining this shorter interval, the analysis investigates whether there is a positive signaling effect of buyback and dividend announcements on share price. (The announcement date was included, since, the publication date would be normally a trading date and investors have the opportunity to respond to such announcements on the same date).

The abnormal return in any given period is the market model residual which is the difference between the stock's actual return and the predicted return based on the market return for that period. Hence, the market adjusted abnormal returns were calculated as:

Where:

$$
\mathrm{AR}_{\mathrm{ij}}=\mathrm{RT}_{\mathrm{ij}}-\mathrm{RM}
$$

$\mathrm{AR}_{\mathrm{ij}}=$ The abnormal return for firm $\mathrm{j}$ on day $\mathrm{i}$

$\mathrm{RT}_{\mathrm{ij}}=$ The actual return for firm $\mathrm{j}$ on day $\mathrm{i}$

The total percentage return to shareholders $\left(\mathrm{RT}_{t}\right)$ on day $t$ is given by the expression:

$$
\left(\mathrm{RT}_{\mathrm{t}}\right)=\left[\left(\mathrm{P}_{\mathrm{t}}-\mathrm{P}_{\mathrm{t}-1}\right)+\mathrm{D}_{\mathrm{t}}\right] / \mathrm{P}_{\mathrm{t}-1}
$$

and $\mathrm{RM}_{\mathrm{i}}$ is the return on the NSE index on day the market adjusted abnormal returns are calculated as in Eq. 1 above. The 5 days cumulative abnormal returns for each firm are calculated as:

$$
5 \text {-Day } \mathrm{CAR}_{\mathrm{ij}}=\Sigma \mathrm{AR}_{\mathrm{ij}} \text {, for days } \mathrm{i}=0,1,2,3,4
$$

Where the announcement day is day 0 . Cumulative abnormal returns are then averaged over the 5 days period starting on the announcement date to obtain the 5 days cumulative average abnormal returns as:

5-Day CAR $=\left(\Sigma \mathrm{CAR}_{j}\right) / \mathrm{n}$ for all firms $\mathrm{j}=1,2, \ldots, \mathrm{n}$

The cumulative abnormal returns prior and after the announcement date are then plotted into graph to examine the signaling effect of buyback and dividend announcement on share price during the 5 days period.

ARCH Model: The ARCH Model is suitable when the error variance in a time series follows an Autoregressive (AR) Model, the model is a Generalized Autoregressive Conditional Heteroskedasticity (GARCH) Model (Manasa and Narayanarao, 2018)

The estimation output header describes the estimation sample and the methods used for computing the coefficient standard errors, the initial variance terms and the variance equation.

The main output from $\mathrm{ARCH}$ estimation is divided into two sections: the upper part provides the standard output for the mean equation while the lower part, labeled "Variance equation", contains the coefficients, standard errors, Z-statistics and p-values for the coefficients of the variance equation.

The ARCH parameters correspond to $\alpha$ and the GARCH parameters to $\beta$. The bottom panel of the output presents the standard set of regression statistics using the residuals from the mean equation. Note that measures such as may not be meaningful, if there are no regresses in the mean equation.

Stock market shows volatility in the data, high volatility and low volatility is shown by the time series. GARCH/ARCH is commonly used in analyzing in finance because of arbitrary volatility.

Before trying GARCH Model for the returns of the stock, heteroskedasticity test is done to check weather volatility exists or not. If it exists, then GARCH Model can be applied.

The development of the general $\operatorname{ARCH}(1,1)$ model consists of two equations viz., mean equation and variance equation (Suresh, 2018). Mean Eq. 1 is:

$$
\mathrm{R}_{\mathrm{t}}=\alpha_{0}+\alpha_{1} \mathrm{R}_{\mathrm{t}-1}+\varepsilon_{\mathrm{t}}
$$


Where:

$\mathrm{R}_{\mathrm{t}}=$ Daily Return of dependent variable

$\mathrm{R}_{\mathrm{t}-1}=$ Daily Return of independent variable

$\alpha_{0}=$ Constant

$\alpha_{1}=$ Coefficient of $\mathrm{R}_{\mathrm{t}-1}$

$\varepsilon_{\mathrm{t}}=$ Residuals

Variance Eq. 2 is:

$$
h_{t}=\alpha_{0}+\alpha_{1} e_{t-1}^{2}+\beta_{1} h_{t-1}
$$

Where:

$h_{\mathrm{t}}=$ Variance of residual term resultant from the mean Eq. 1

$\alpha_{0}=$ Constant

$\alpha_{1}=$ Coefficient of $\mathrm{e}_{\mathrm{t}-1}^{2}$

$\mathrm{e}_{\mathrm{t}-1}^{2}=\mathrm{ARCH}$ term

$\mathrm{h}_{\mathrm{t}-1}=$ GARCH term

$\beta_{1}=$ Coefficient of $h_{t-1}$

To analyze the index and stock which have impact on the volatility, an exogenous dummy variable $\mathrm{D}_{\mathrm{f}}$ is taken in the variance equation. If the dummy variable is found at 0.05 level of significance, the stock has an effect on the volatility of spot market. If this coefficient is found significant, it shows the stock transactions lead to change in the spot market volatility. Then the variance equation is as follows:

$$
h_{t}=\alpha_{0}+\alpha_{1} e_{t-1}^{2}+\beta_{1} h_{t-1}+\gamma_{1} D_{f}
$$

Where:

$\mathrm{D}_{\mathrm{f}}=$ Dummy variable

$\gamma_{1}=$ Coefficient of $D_{f}$

The model will be right when residuals satisfy for no serial correlation in the span of testing the serial correlation:

$$
\sigma_{t}^{2}=¥+\beta \cdot \sigma_{t-1}^{2}+\alpha \cdot X_{t-1}^{2}
$$

where, $\gamma, \alpha$ and $\beta$ are the predicted parameters.

\section{RESULTS AND DISCUSSION}

Market model is used in many event studies to estimate normal performance of a stock. This study mainly focuses on stock buybacks; comparatively the sample of buyback announcements is thin. Firms that repurchase shares are on an average small. Cumulative Abnormal Returns (CAR) is consistent with the expectations, there is a positive reaction of market for both stock repurchase and dividend announcements. The CAR calculated for share repurchase and dividends shows the existence of positive signaling of share price behavior in the market. Figure 1 and 2 are plotted with 5 days pre-CAR and 5 days post-CAR confirms that there is positive signaling effect

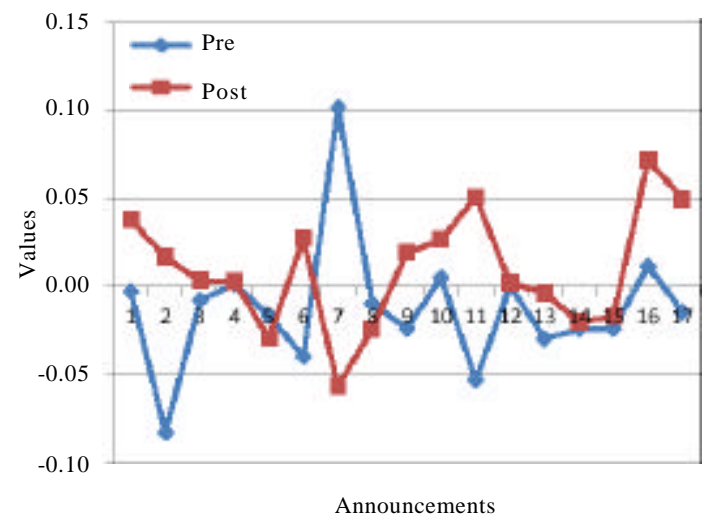

Fig. 1: Share price behavior around buyback announcements

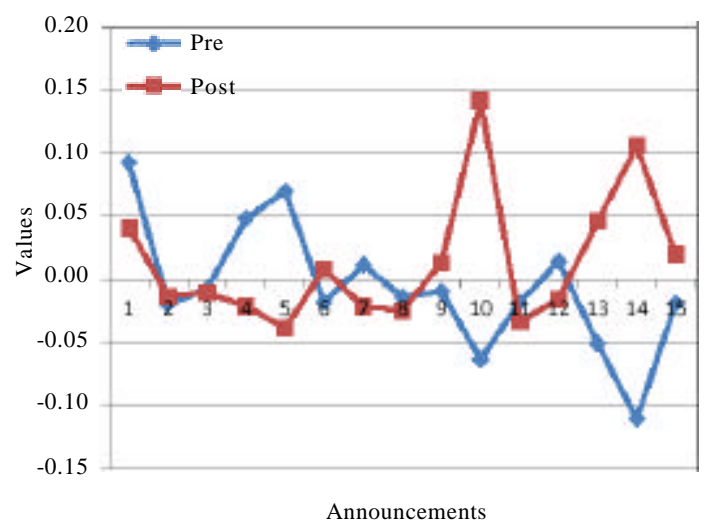

Fig. 2: Share price behavior around dividend announcements

\begin{tabular}{|c|c|c|c|c|c|c|}
\hline \multirow[b]{2}{*}{ Companies } & \multicolumn{3}{|c|}{ Mean equation } & \multicolumn{3}{|c|}{ Variance equation } \\
\hline & $A_{0}$ & A & $\alpha$ & $\alpha_{1}$ & $\beta 1$ & $\ddot{z}_{1}$ \\
\hline \multirow[t]{2}{*}{ Ambika mills } & 1.362 & & & & $982^{* *}$ & 0.69 \\
\hline & & & & & & 0.4896 \\
\hline \multirow{2}{*}{ Coal India } & -1.4 & & & & & \\
\hline & & & & & & 0.0078 \\
\hline \multirow[t]{2}{*}{ Dr. Reddy lab } & 0.2076 & $7.7217^{* *}$ & 2.12 & $3.8359^{* *}$ & $3.0837^{* *}$ & -0.9698 \\
\hline & 0.8355 & 0.0000 & 0.0338 & 0.0000 & 0.0020 & 0.3321 \\
\hline
\end{tabular}

Table 1: Results of estimated GARCH Model (ARCH $(1,1)$ Model) Equation: $\sigma_{\mathrm{t}}^{2}=\$+\beta \cdot \sigma_{\mathrm{t}-1}^{2}+\alpha . \mathrm{X}_{\mathrm{t}-1}^{2}$

${ }^{* *}$ Indicates statistical significance at $1 \%$ level

of the announcements. Auto regressive conditional heteroskedasticity Model ARCH shows that buyback and dividend announcement has an impact on share prices. Table 1 shows that buyback and dividend announcement has an impact on share prices.

Identifying an announcement which has higher signaling power than the other is the next step. For which mean CAR of repurchase announcement $0.14^{*}$ was compared with the mean CAR of dividend announcement $0.11^{*}$ (statistically significant at 0.05 level). Difference 


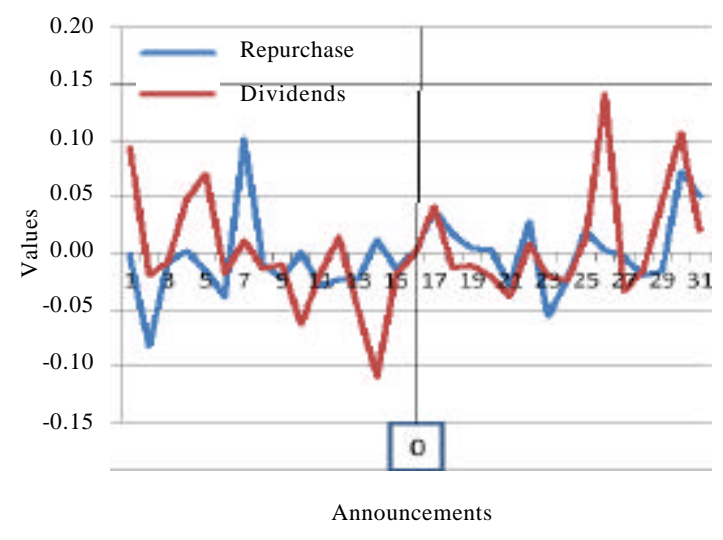

Fig. 3: CAR around announcement date

occurred between means was ignorable, even then it can be concluded that the CAR around share buyback are higher than the CAR around dividend announcement. It shows that the market reaction is comparatively larger for buyback announcements than dividends.

The next is to find out whether buyback and dividend announcement has an impact on share price behaviour, this step uses ARCH $(1,1)$ Model.

Autoregressive conditional heteroskedasticity Model is calculated using dummy variables in order to find out whether share buyback and dividend announcement has an impact on share prices, the above mentioned formula has been used for the calculations and it shows that this model is significant.

Cumulative average abnormal returns for both stock repurchases and dividend announcements around the announcement date were plotted. In Fig. 3 the left part of figure represents a time period, from 5 days prior to announcements and the right part represents the time period of 5 days after announcements. The center line represents the announcement day that is day 0 . It shows that stock buybacks have more abnormal return upon announcements than dividend announcements.

\section{CONCLUSION}

In Indian stock market buyback has a significant role in order to increase the share holders wealth and value of the firm; it allows companies to sustain in the market. This study investigates the signaling effect of share buyback and dividend announcement by applying 11 days event window. For buyback and dividends market immediately signaled an upward swing but this positive signaling existed only for a couple of days after announcement. In the short term event study window of 11 days, the result revealed that when the share price and the cumulative abnormal return increased immediately the very next day of the announcement, it kept on increasing. The possible explanation is that in the Indian market the market reaction for buyback and dividend announcement was complete within 1 day or 2 days. At the mean time, open market share repurchase leads in advantage of changes in share price and flexibilities to companies that face uncertain cash flows during the repurchase period. And $\mathrm{ARCH}$ effect is found in all the stocks and volatility in the GARCH Model, it shows that there is an impact of buyback and dividend announcements on share prices around the announcement date.

\section{REFERENCES}

Andres, C., A. Betzer, M. Doumet and E. Theissen, 2018. Open market share repurchases in Germany: A conditional event study approach. Abacus, 54: 417-444.

Andriosopoulos, D. and M. Lasfer, 2015. The market valuation of share repurchases in Europe. J. Bank. Finance, 55: 327-339.

Chemmanur, T.J., Y. Cheng and T. Zhang, 2010. Why do firms undertake accelerated share repurchase programs?. Master Thesis, Boston College and Florida State University, Tallahassee, Florida.

Evgeniou, T., J. Peress, T. Vermaelen and L. Yue, 2018. Network centrality and managerial market timing ability: Evidence from open-market repurchase announcements. SSRN. Electr. J., 1: 1-60.

Manasa, N. and S. Narayanarao, 2018. A study on impact of banknifty derivatives trading on spot market volatility in India. Acad. Accounting Financial Stud. J., 22: 1-9.

Suresh, N., 2018. Does all macro-economic factors contributes equally for Foreign Direct Investment (FDI) Inflows in India?: An empirical study on macrovariables. Proceedings of the 8th International Conference on Advances in Economics, Management and Social Study (EMS 2018), February 3-4, 2018, IRED, New York, USA., ISBN:978-1-63248-146-7, pp: 10-16.

Tirumalvalavan, P. and K. Sunitha, 2006. Share price behaviour around buy backs in India. J. Manage. Res., 1: 27-37. 